\title{
Influence of varying environmental conditions on biennial bearing habit of Kinnow fruit (Citrus nobilis Lour x $C$. deliciosa Tenora) grown at different clusters in the Punjab province, Pakistan
}

\author{
Rab Nawaz ${ }^{1}$, Nadeem Akhtar Abbasi ${ }^{1}$, Ishfaq Ahmad Hafiz ${ }^{1}$ \& Azeem Khalid ${ }^{2}$
}

\section{SUMMARY}

Influence of varying environmental conditions on biennial bearing of Kinnow mandarin was assessed at three main citrus clusters in the Punjab province, Pakistan. The selected orchards of identical features are located in districts Sargodha, Toba Tek Singh (TTS) and Vehari. The experiment was laid out in randomized complete block design by using analysis of variance technique. Fruit bearing habit was recorded first and second seasons and biennial bearing trend was observed at TTS and Vehari. Vegetative three flushes were slightly changed due to biennial bearing in warm districts TTS and Vehari. More evenness in fruit yield and quality parameters was recorded at Sargodha while significant change was observed at TTS and Vehari. Timely harvesting of orchards at Sargodha district showed regular fruit-bearing in both seasons and delayed harvesting induced biennial bearing trend more at TTS and Vehari. More physiological and ripening stage fruit drop was observed in warm conditions of Vehari and TTS while an increasing level was recorded in rainy season at Sargodha with insignificant differences in both seasons.

Index terms: Citrus nobilis $x$ C. deliciosa, alternate bearing, varying environmental conditions.

Influência das variáveis ambientais na bienalidade produtiva de tangerina Kinnow (Citrus nobilis Lour x C. deliciosa Tenora) cultivada em diferentes províncias de Punjab, Paquistão

\section{RESUMO}

A influência de diferentes condições ambientais no manejo da alternância de produção da tangerina Kinnow foi avaliada em três principais regiões produtoras de citros na província de Punjab, Pakistão. Os pomares selecionados de características idênticas estão localizados nos distritos Sargodha, Toba Tek Singh (TTS) e Vehari. O experimento foi instalado em delineamento de blocos casualizados, utilizando a técnica de análise de variância. $O$ hábito de frutificar foi registrado na primeira e segunda temporadas e a tendência de alternância foi observada no TTS e Vehari. As três descarga vegetativas foram levemente alteradas devido à presença bienal nos distritos quentes TTS e Vehari. Mais uniformidade nos parâmetros de produção e qualidade dos frutos foi registrada em Sargodha, enquanto mudanças significativas foram observadas em TTS e Vehari. A colheita oportuna de pomares no distrito de Sargodha mostrou frutificação regular em ambas as estações e a tendência de alternância de produção induzida pela colheita atrasada mais no TTS e Vehari.

\footnotetext{
${ }^{1}$ Department of Horticulture, Pir Mehr Ali Shah- Arid Agriculture University, Rawalpindi, Pakistan

2 Department of Environmental Sciences, Pir Mehr Ali Shah- Arid Agriculture University, Rawalpindi, Pakistan

Corresponding author: Department of Horticulture, PMAS-AridAgriculture University, Rawalpindi, Pakistan. E-mail: nadeemabbasi65@yahoo.com
} 
Observou-se maior queda fisiológica e de frutos maduros nas condições quentes de Vehari e TTS, enquanto um nível crescente foi registrado na estação chuvosa em Sargodha, com diferenças insignificantes nas duas estações.

Termos de indexação: Citrus nobilis $x$ C. deliciosa, alternância de produção, condições ambientais variáveis.

\section{INTRODUCTION}

Kinnow mandarin is hybrid of King (Citrus nobilis Lour) and Willow (Citrus deliciosa Tenore) has been introduced in the Subcontinent during the dwindling era of British in 1942 at Lyallpur Agriculture College, now named as University of Agriculture Faisalabad and acquired commercialization in 1960's with start of export in 1990's. Now this fruit has monopolized citrus industry of Pakistan with 91\% area and same level of production. It is mainly growing in four main clusters of the Punjab province led by in central to northern side Sargodha and adjacent districts (M.B Din and Chiniot) with 60-62\% area, followed by central Punjab district Toba Tek Singh and adjunct area (Faisalabad and Jhang) with $10-12 \%$ area and in Southern side of the Punjab (Vehari, Sahiwal and Khanewal) with $15-18 \%$ share in area and newly emerging fourth cluster in Thal districts of western side of the Punjab (Bhakhar and Layyah) with 5-6\% area (Ghafoor et al., 2008; Pakistan, 2017; Nawaz et al., 2019a, 2019b).

Kinnow mandarin is exclusive exportable citrus of Pakistan by touching worth of 222 million US dollars and 370 thousand tons during the season 2017-18 (Nawaz et al., 2019b, 2019c). It is highly valuable crop of country by employing huge labors and rich source of income to farmers' community. Pakistan just export (10-12\%) of her total Kinnow fruit produce while rest is consumed at domestic markets (TDAP, 2018; PHDEC, 2018). Fruit quality is top most priority of buyers while purchasing fruits either to sell at domestic markets or to processing units for export purpose. In light-bearing year, growers, consumers and processors of Kinnow fruits are more at risk with low income to farmers, costly fruit for consumers and mediocre quality for export (TDAP, 2017). Pakistani Kinnow is excellent in outlook, quality, flavor and taste when compared to fresh mandarin across the world but due to export barriers and rigorous certifications process, just fetch $2 \%$ in high returning markets of EU and advanced countries (Ahmed, 2005). Climate change has increased risk of citrus fruit grown in different clusters with more pests pressure and matured fruit drops at warm conditions (Nawaz et al., 2020b) along with more accretion of agrometeorological indices (Nawaz et al., 2020a) and increasing level of pest-diseases (Nawaz et al., 2019a). Citrus fruit quality is maintained through management of orchard (Mahmood \& Sheikh, 2006) and also minimizing biennial bearing. Similarly, external environmental conditions can decides fruit external and internal quality (Ladaniya, 2011), in addition citrus fruit bearing habit,

In era of increasing trend of greenhouse gases to rise earth temperature (IPCC, 2007) has increased abiotic and biotic stress on crops (Ullah et al., 2015) and also on citrus (Nawaz et al., 2019a). More fruit drop is seen in extreme weather conditions like heat-wave and smog time (Nawaz et al. 2020b) by directly affecting on-tree fruit quantity and subsequent season bearing habit (Wheaton, 1992). More alternate bearing and quality deterioration are seen in climate change era (Zekri, 2011) and altered agricultural systems and crop preference (Parry et al., 2004). Strategies of different nature are explored to mitigate environmental detrimental effects on annual crops (Burton \& Lim, 2005) with little focus on perennial fruits with exception of citrus Valencia orange regarding yield (Tubiello et al., 2002). Being a perennial fruit, citrus stand many years in field is become more vulnerable to vagaries of weather due to slow adoption in changing climatic variables (Jones et al., 2005), is more inclined toward irregular bearing with dented fruit quality (Hield \& Hilgeman, 1969).

Irregular bearing habits produce heavy crops in first year and light in second is termed as alternate or biennial bearing (Monselise \& Goldschmidt, 1982) that is the leading cause of imperfection marketing of irregular supply mechanism. Similarly, glut of fruit in markets during on-year delay harvesting time with less flowering and low fruit-setting while light bearing crop earlier harvested to induce more fruiting for coming season. This phenomenon is termed as alternate bearing to affect citrus orchard productivity and profitability (Davis et al., 2004) along with marketing issues like superfluity; uneven supply and price oscillation (Moss et al., 1974). In Pakistan, biennial bearing impinge on supply-chain by recording $40 \%$ (Johnson, 2006) and $35 \%$ fruit loss (Khan, 2008) with recoding more profit margin of brokers, buyers and exporters during heavy bearing season (Usman et al., 2018). 
Present study was designed in main Kinnow growing districts Sargodha, TTS and Vehari of representing three main citrus clusters in the Punjab province. Field based study was designed to select identical features Kinnow plants and survey to citrus stakeholders perception. Impact of varying environmental conditions on fruit bearing habit was analyzed.

\section{MATERIALS AND METHODS}

The present study was conducted in three main citrus growing districts of the Punjab province, Pakistan namely Sargodha $\left(32.0837^{\circ} \mathrm{N}, 72.6719^{\circ} \mathrm{E}\right)$ altitude $189 \mathrm{~m}$, Toba Tek Singh $\left(30.9727^{\circ} \mathrm{N}, 72.4850^{\circ} \mathrm{E}\right)$ altitude $161 \mathrm{~m}$ and Vehari $\left(30.0452^{\circ} \mathrm{N}, 72.3489^{\circ} \mathrm{E}\right)$ altitude $140 \mathrm{~m}$. The research work performed in first season (2017-18) and second season (2018-19).

\section{Selection of orchards}

Identical plants characteristics like age, planting density and grafted on rootstock (Rough lemon) were chosen (Nawaz et al., 2020b) while tagging 36 branches/twigs at different canopy positions (Nawaz et al., 2020a) to record data on monthly basis.

\section{Climatic/weather data}

Climatic/weather data of Sargodha and TTS was taken from Pakistan Meteorological Department and Vehari from the office of Deputy Director Agriculture (Extension) Vehari.

\section{Measurement of bearing habit}

Three orchards were selected in each district to count bearing habit of 100 Kinnow plants in each orchard in growing season 2017-18 and 2018-19 and calculated number of light, medium and heavy bearing plants.

\section{Flush quantification}

In selected orchards, vegetative three flushes were quantified by using a quadrate $\left(0.5 \times 0.5 \times 0.5 \mathrm{~m}^{3}\right)$ and counted twigs inside and value expressed in percentage.

\section{Fruit yield and grades percentage}

In selected orchards fruit yield and grades percentage were calculated at harvesting by counting number of fruits and grades (A, B and $\mathrm{C}$ ) percentage.

\section{Orchard harvesting trend}

A survey in selected clusters was performed to investigate harvesting timing during both seasons.

\section{Fruit drop trend}

Fruit drop percentage of three distinct stages, physiological(April-May), rainy season (June to September) and maturing (October-December) was calculated from tagged branches.

\section{Statistics design}

Three biological replicates were selected in a randomized complete block design by using analysis of variance technique on Statistix 8.1 software by keeping LSD value $\leq 5 \%$ significance level.

\section{RESULTS AND DISCUSSIONS}

Data analysis showed significant economic impact on citrus (Kinnow mandarin) during on-year and off-year, which was explained and discussed under.

\section{Weather data of three locations}

Monthly basis average data of three selected sites showed clear-cut differences in temperature, relative humidity, rainfall and actual sunshine hours. Annual higher temperature was recorded at Vehari $\left(27.11^{\circ} \mathrm{C}\right)$, followed by TTS $\left(25.19{ }^{\circ} \mathrm{C}\right)$ and lower at Sargodha $\left(24.34{ }^{\circ} \mathrm{C}\right)$. Annual humidity was recorded $(66.80$ and $66.51 \%)$ at Sargodha and TTS and lower $(55.64 \%)$ at Vehari (Table 1). Maximum average rainfall on monthly basis was recorded at Sargodha $(42.16 \mathrm{~mm})$, followed by TTS $(29.15 \mathrm{~mm})$ and lower at Vehari $(12 \mathrm{~mm})$. Average monthly basis, more actual sunshine hours were counted 
Table 1. Weather data of three districts (Pakistan)

\begin{tabular}{|c|c|c|c|c|c|c|c|c|c|c|c|c|}
\hline \multirow{3}{*}{ Months } & \multicolumn{12}{|c|}{ Weather data of three research sites } \\
\hline & \multicolumn{3}{|c|}{$\begin{array}{l}\text { Average temperature } \\
\qquad\left({ }^{\circ} \mathrm{C}\right)\end{array}$} & \multicolumn{3}{|c|}{$\begin{array}{l}\text { Average relative } \\
\text { humidity }(\%)\end{array}$} & \multicolumn{3}{|c|}{$\begin{array}{c}\text { Rainfall } \\
(\mathrm{mm})\end{array}$} & \multicolumn{3}{|c|}{$\begin{array}{l}\text { Actual sunshine } \\
\text { (hours) }\end{array}$} \\
\hline & SGD* & TTS & VEH & SGD & TTS & VEH & SGD & TTS & VEH & SGD & TTS & VEH \\
\hline Jan & 12.17 & 12.76 & 14.13 & 80.05 & 81.05 & 73.68 & 18.84 & 5.41 & 7.50 & 114.60 & 145.70 & 155.25 \\
\hline Feb & 16.34 & 16.80 & 17.26 & 65.93 & 63.48 & 61.65 & 14.02 & 6.41 & 5.50 & 188.80 & 190.95 & 198.75 \\
\hline Mar & 21.62 & 22.13 & 24.94 & 63.68 & 65.32 & 57.98 & 26.30 & 13.96 & 3.50 & 222.15 & 219.65 & 234.31 \\
\hline Apr & 27.56 & 28.73 & 31.24 & 53.67 & 51.27 & 41.03 & 73.59 & 44.73 & 1.00 & 250.70 & 237.15 & 250.80 \\
\hline May & 31.56 & 32.39 & 35.83 & 49.35 & 46.98 & 32.85 & 39.03 & 21.37 & 2.00 & 256.05 & 230.65 & 255.31 \\
\hline Jun & 32.59 & 32.80 & 35.78 & 59.00 & 62.85 & 40.70 & 58.84 & 48.96 & 8.50 & .25 & 18 & 255.25 \\
\hline Jul & 31.57 & 32.96 & 33.20 & 72.47 & 71.37 & 55.22 & 167.17 & 102.46 & 81.00 & 211.75 & 218.80 & 230.45 \\
\hline Aug & 31.98 & 32.62 & 33.03 & 70.87 & 68.76 & 55.73 & 52.53 & 79.06 & 1.00 & 214.95 & 208.45 & 238.75 \\
\hline Sep & 29.66 & 30.78 & 33.88 & 70.63 & 67.13 & 51.87 & 49.02 & 20.96 & 0.00 & 230.95 & 222.55 & 233.90 \\
\hline Oct & 25.56 & 26.93 & 29.65 & 63.76 & 64.60 & 61.00 & 3.01 & 0.01 & 0.00 & 225.10 & 229.55 & 239.40 \\
\hline Nov & 18.03 & 18.84 & 19.78 & 80.02 & 82.40 & 64.42 & 1.53 & 2.51 & 0.00 & 187.40 & 151.20 & 158.75 \\
\hline Dec & 13.43 & 14.56 & 16.65 & 72.23 & 72.94 & 71.60 & 7.52 & 4.06 & 4.00 & 199.95 & $184 . .78$ & 196.3 \\
\hline Avg & 24.34 & 25.19 & 27.11 & 66.80 & 66.51 & 55.64 & 42.61 & 29.15 & 12.00 & 209.80 & $210 . .60$ & 220.95 \\
\hline
\end{tabular}

*Abbreviation: SGD (Sargodha), TTS (Toba Tek Singh), VEH (Vehari).

at Vehari (220.95 hours), followed by (210.6 hours) at TTS and less in Sargodha (209.8 hours) (Table 1).

Vehari is located in southern side of the Punjab province has dry warm conditions having more temperature and low humidity from April till September than other districts and low rainfall. As Sargodha is located in northern side has low temperature and more rainfall and less sunshine hours. Whereas, annual humidity level of TTS is equal to Sargodha having slightly high temperature and significantly less rainfall when compared with Sargodha. All three sites showed climatic variations which directly influenced on fruit growth phases and plant physiology.

\section{Measurement of bearing habit}

Among different bearing habits out of selected 100 plants orchards, maximum heavy-bearing plants were recorded at district Vehari (30), followed by TTS (25) and less in Sargodha (10) during first season and in second season heavy-bearing plants were observed in Sargodha (15) followed by TTS (10) and less at Vehari (8). Medium-bearing plants were recorded more at Sargodha (70 and 55), followed by TTS (60 and 50) and less in Vehari (55 and 45) during first and second seasons, respectively. Low-bearing plants were counted in Sargodha (20 and 30), TTS (15 and 40) and Vehari (15 and 47), respectively during first and second seasons. Data are shown in Table 2.
Biennial bearing habit occur to individual plant or within a plant few branches or to whole block in cluster (Monselise \& Goldschmidt, 1982) with more trend is seen in mandarin group of citrus (Wheaton, 1992). In Vehari and TTS, Kinnow fruit is mainly consumed at domestic markets with start of late harvesting and more intensity in heat-wave started during onset of summer spell with recording more fruit drop. Resultantly, more phenomena of biennial bearing observed were observed in these warm districts. In Sargodha, Kinnow fruit exporting units start earlier and spot-picking of fruit has reduced load as well as timely harvesting yielded more evenness in bearing habit which was recorded in present study. Goldschmidt \& Golomb (1982) reported that heavy-bear citrus plant lack flowering for next year and cause alternate bearing habit. Heavy-bearing plants were more recorded at Vehari and TTS in first season and low-bearing in second season. Timely harvesting and more medium-bearing plants were recorded at Sargodha, resulted in less biennial bearing issues. Timely harvesting and medium-bearing citrus plants maintain a balance in floral and vegetative flush with evenness habit of fruit bearing (Garcia-Luis et al., 1995) to justify present work.

\section{Flush quantification}

Three different flushes viz; spring, summer and fall were quantified during growing first and second seasons with showing a significant statistical difference in Table 3. 
Table 2. Bearing habit of Kinnow fruit in first and second season under varying environmental conditions

\begin{tabular}{|c|c|c|c|c|c|c|}
\hline & \multicolumn{2}{|c|}{ Sargodha } & \multicolumn{2}{|c|}{ T.T Singh } & \multicolumn{2}{|c|}{ Vehari } \\
\hline & $\begin{array}{c}\text { First } \\
\text { season }\end{array}$ & $\begin{array}{l}\text { Second } \\
\text { season }\end{array}$ & $\begin{array}{c}\text { First } \\
\text { season }\end{array}$ & $\begin{array}{l}\text { Second } \\
\text { season }\end{array}$ & $\begin{array}{c}\text { First } \\
\text { season }\end{array}$ & $\begin{array}{l}\text { Second } \\
\text { season }\end{array}$ \\
\hline Heavy-bearing (No. of plants) & $10 \pm 2$ & $15 \pm 3$ & $25 \pm 2$ & $10 \pm 2$ & $30 \pm 2$ & $8 \pm 2$ \\
\hline Medium-bearing (No. of plants) & $70 \pm 2.83$ & $55 \pm 1.73$ & $60 \pm 1.16$ & $50 \pm 1.16$ & $55 \pm 2$ & $45 \pm 1.16$ \\
\hline Light-bearing (No. of plants) & $20 \pm 1.41$ & $30 \pm 3.51$ & $15 \pm 2.89$ & $40 \pm 1.15$ & $15 \pm 1.41$ & $47 \pm 6.24$ \\
\hline
\end{tabular}

Data are presented in means $( \pm \mathrm{SD}) . \mathrm{SD}=$ standard deviation.

Table 3. Quantification of vegetative flushes during first and second seasons

\begin{tabular}{|c|c|c|c|c|c|c|}
\hline & \multicolumn{2}{|c|}{ Sargodha } & \multicolumn{2}{|c|}{ T.T Singh } & \multicolumn{2}{|c|}{ Vehari } \\
\hline & $\begin{array}{c}\text { First } \\
\text { season }\end{array}$ & $\begin{array}{c}\text { Second } \\
\text { season }\end{array}$ & $\begin{array}{c}\text { First } \\
\text { season }\end{array}$ & $\begin{array}{l}\text { Second } \\
\text { season }\end{array}$ & $\begin{array}{c}\text { First } \\
\text { season }\end{array}$ & $\begin{array}{l}\text { Second } \\
\text { season }\end{array}$ \\
\hline Spring flush (\%) & $60 \pm 2$ & $62 \pm 2.53$ & $50 \pm 2$ & $56 \pm 2$ & $55 \pm 3$ & $60 \pm 2$ \\
\hline Summer flush $(\%)$ & $30 \pm 2$ & $26 \pm 1.13$ & $35 \pm 2.65$ & $30 \pm 1.53$ & $32 \pm 4.36$ & $28 \pm 1$ \\
\hline Autumn flush (\%) & $10 \pm 2$ & $12 \pm 1.53$ & $15 \pm 3$ & $14 \pm 1.53$ & $13 \pm 2.65$ & $12 \pm 1$ \\
\hline
\end{tabular}

Data are presented in means $( \pm \mathrm{SD}) . \mathrm{SD}=$ standard deviation.

In first season, spring flush was recorded (60,50 and 56\%), summer flush (30, 35 and 32\%) and autumn flush $(10,15$ and $13 \%)$ at Sargodha, TTS and Vehari districts, respectively. In second season, spring flush was recorded $(62,56$ and $60 \%)$, summer flush $(26,30$ and $28 \%)$ and autumn (12, 14 and 12\%) in districts Sargodha, TTS and Vehari, respectively.

Dalal et al. (2013) recorded maximum spring and minimum autumn flush of Kinnow mandarin. Bower (2007) attributed summer flush lower than spring due to hard environmental conditions in summer season. In present work, spring flush in both season and all three districts counted more than half of total annual flush with one-third to one-fourth share of summer and less contribution of autumn flush. No significant differences were observed at Sargodha districts in three vegetative flushes but slight variations were seen at TTS and Vehari in spring and summer flushes due to biennial nearing habits. More summer flush was recorded at TTS and Vehari as warm conditions earlier accrued growing degree days as required for fruit cell division. Similar results in citrus are observed by Sharma et al. (2017) of recording prior cell division completion and starting of cell enlargement in warm conditions grown fruits. In current work, both cell division and cell enlargement commenced prior to Sargodha in districts TTS and Vehari with earlier sprouting of summer flush vegetative growth. More summer flush was recorded in second season due to low bearing of Kinnow fruit at TTS and Vehari while evenness in all three flushes quantification was seen at Sargodha.
Photoassimilates more streamlined towards fruit growth and development, yielded low quantification of summer and spring flushes in heavy cropping season (Iglesias et al., 2007). Resulting, less growth in summer and fall flushes as source-sink relationship of carbohydrate determines trees vegetative and reproductive growth (Flore \& Lakso, 1986; Goldschmidt 1999). Similar findings regarding less summer and fall flushes were observed in current work. Present results agree with the evidence that developing fruits strive for photoassimilates (Goldschmidt \& Koch, 1996).

\section{Fruit yield and grades percentage}

Yield parameters including total no. of fruits, A-grade, B- grade and C-grade fruits harvesting per plant are presented in Table 4 which possessed significant differences.

In first season, total number of fruits per plant (755,984 and 735 fruits),A-grade fruits (18.28, 13.88 and $10.43 \%$ ), B-grade fruits $(44.24,45.52$ and $48.23 \%)$ and C-grade fruits (37.48, 40.06 and $41.34 \%)$ were counted at Sargodha, TTS and Vehari, respectively. In second season, total number of fruits per plant (725, 650 and 467 fruits), A-grade (15.4, 9.46 and 8.71\%), B-grade (39.87, 53.19 and 56.36\%) and C-grade (44.64, 37.35 and $34.93 \%$ ) were harvested in districts Sargodha, TTS and Vehari, respectively. Non-significant difference in yield parameters was observed at Sargodha during both seasons of depicting minute phenomena of biennial bearing. However, a significant 
Table 4. Yield trend in biennial bearing under varying environmental conditions

\begin{tabular}{|c|c|c|c|c|c|c|}
\hline \multirow[b]{2}{*}{ Yield parameters } & \multicolumn{2}{|c|}{ Sargodha } & \multicolumn{2}{|c|}{ T.T Singh } & \multicolumn{2}{|c|}{ Vehari } \\
\hline & $\begin{array}{c}\text { First } \\
\text { season }\end{array}$ & $\begin{array}{l}\text { Second } \\
\text { season }\end{array}$ & $\begin{array}{c}\text { First } \\
\text { season }\end{array}$ & $\begin{array}{l}\text { Second } \\
\text { season }\end{array}$ & $\begin{array}{c}\text { First } \\
\text { season }\end{array}$ & $\begin{array}{l}\text { Second } \\
\text { season }\end{array}$ \\
\hline No. of fruits/plant* & $755.51 \pm 10.61$ & $725.34 \pm 12.27$ & $984.54 \pm 23.46$ & $650.61 \pm 11.49$ & $735.97 \pm 25.41$ & $467.28 \pm 29.26$ \\
\hline A-grade $\%$ & $18.28 \pm 1.25$ & $15.49 \pm 2.58$ & $13.88 \pm 1.22$ & $9.46 \pm 2.32$ & $10.43 \pm 2.43$ & $8.71 \pm 3.42$ \\
\hline B-grade $\%$ & $44.24 \pm 5.14$ & $39.87 \pm 6.30$ & $45.52 \pm 3.42$ & $53.19 \pm 6.23$ & $48.23 \pm 4.04$ & $56.36 \pm 5.03$ \\
\hline C-grade $\%$ & $37.48 \pm 9.29$ & $44.64 \pm 8.28$ & $40.6 \pm 5.13$ & $37.35 \pm 3.12$ & $41.34 \pm 3.75$ & $34.93 \pm 3.23$ \\
\hline
\end{tabular}

Data are shown in mean $( \pm \mathrm{SD}) .{ }^{*} \mathrm{~A}, \mathrm{~B}$ and $\mathrm{C}$ (Grade-A, Grade-B and Grade-C).

difference was observed in first and second seasons in Kinnow fruit yield at TTS and Vehari of indicating more biennial bearing habit of orchard.

Fruit yield and quality is affected at the time of fruit growth due to climate variables (Yakushiji et al., 1996) and citrus fruit yield reduced to $1 / 4^{\text {th }}$ in global warming (Zekri \& Rouse, 2002), besides being observing deterioration in fruit quality (Holland et al., 2002). In current work, more quality deterioration was recorded at TTS and Vehari. Temperature was recorded more at Vehari, low fruit-setting and more premature drop was observed in both biennial bearing habits. In first season, fruit overall yield and quality like fruit grades were better due to more number of fruit while in second season, yield and grades percentage was reduced. In Sargodha, timely harvesting and medium-bearing habit maintained a source-sink relation which was further enhanced by moderate temperature and more chilling hour to retard biennial bearing tendency. Fruit A-grade quality is based on size and cosmetic outlook i.e., free from peel blemishes induced by abiotic (wind scares) and biotic (pest-diseases) incidences. More A-grade fruits were recorded at Sargodha and less at Vehari in first and second season of indicating stress on fruit quality in both districts. Pests pressure was more at Vehari while less at Sargodha and vice versa in disease case. Biennial bearing also affected fruit yield parameters including grading quality as was observed in present study which in line with the work of Chelong \& Sdoodee (2013) on Shogan (Citrus reticulata Blanco) in Thailand.

\section{Orchard harvesting trend}

Orchards harvesting trend was surveyed in three different districts of the Punjab, presented in Table 5. At the end of January, more orchards were harvested at Sargodha (50 and 55\%), followed by TTS (40 and 60\%) and less at Vehari (30 and 36\%) in first season and second season, respectively. Similar trend of more orchards harvesting was observed in the end of February by recording at Sargodha (80 and 85\%), TTS (75 and 86\%) and Vehari (65 and 75\%) in first and second seasons, respectively. At $15^{\text {th }}$ March, maximum harvesting was done in Sargodha (98 and 100\%), followed by TTS (93 and 97\%) and minimum in Vehari (92 and 96\%) in first and second season, respectively.

Delayed harvesting in avocado reduced yield and initiated alternate bearing (Whiley et al., 1996) with same trend was seen at TTS and Vehari. As harvesting was delayed, more biennial bearing was seen in these districts as compared to Sargodha where timely harvesting retard this phenomena. Fruit bearing affects plant metabolic processes involving coenzymes, sugars and amino acids (Nishikawa et al., 2016) and late harvesting accelerated it and affected next season crop. Late harvesting in both Vehari and TTS during heavy bearing crop resulted in low crop in next year and timely harvesting in Sargodha has reduced effect of alternate bearing. In Sargodha, well-established processing units for export have positive effects on timely picking of ripened fruits while in rest of two districts fruits harvesting depend on local markets and during on-year bearing period, more glut in market and low price have forced to delay harvesting until reasonable response from market. At first day of March, in Sargodha district maximum orchards were harvested with no effect on flowering of next crop while late at TTS and Vehari affected fruit-setting.

\section{Fruit drop trend}

Perusal of data regarding fruit drop in three different stages are presented in Table 6, in first and second seasons.

Physiological fruit drop was recorded in Sargodha (51.61 and 49.25\%), TTS (54.82 and 51.21\%) and Vehari (51.42 and 48.2\%) in first and second season, respectively. Rainy season (June-September), fruit drop was recorded at Sargodha (25.22 and 22.35\%), TTS (19.6 and 16.2\%) and Vehari (18.36 and 15.32\%) in first and second season, 
Table 5. Kinnow orchards harvesting trend in biennial bearing under varying environmental conditions

\begin{tabular}{|c|c|c|c|c|c|c|}
\hline & \multicolumn{6}{|c|}{ Orchards harvesting trend in selected Kinnow fruit clusters } \\
\hline & \multicolumn{2}{|c|}{ Sargodha } & \multicolumn{2}{|c|}{ T.T Singh } & \multicolumn{2}{|c|}{ Vehari } \\
\hline & $\begin{array}{c}\text { First } \\
\text { season }\end{array}$ & $\begin{array}{l}\text { Second } \\
\text { season }\end{array}$ & $\begin{array}{c}\text { First } \\
\text { season }\end{array}$ & $\begin{array}{l}\text { Second } \\
\text { season }\end{array}$ & $\begin{array}{c}\text { First } \\
\text { season }\end{array}$ & $\begin{array}{l}\text { Second } \\
\text { season }\end{array}$ \\
\hline End of January (\%) & $50 \pm 3.25$ & $55 \pm 4.14$ & $40 \pm 3.65$ & $60 \pm 4.15$ & $30 \pm 5.36$ & $36 \pm 4.08$ \\
\hline End of February (\%) & $80 \pm 2.95$ & $85 \pm 3.21$ & $75 \pm 2.89$ & $86 \pm 3.42$ & $65 \pm 3.45$ & $75 \pm 5.02$ \\
\hline Midst of March (\%) & $96 \pm 1.84$ & $98 \pm 1.02$ & $95 \pm 1.84$ & $97 \pm 1.21$ & $93 \pm 2.11$ & $95 \pm 2.48$ \\
\hline
\end{tabular}

Data are shown in mean $( \pm \mathrm{SD})$. $\mathrm{SD}=$ standard deviation.

Table 6. Kinnow fruit drop trend in biennial bearing under varying environmental conditions

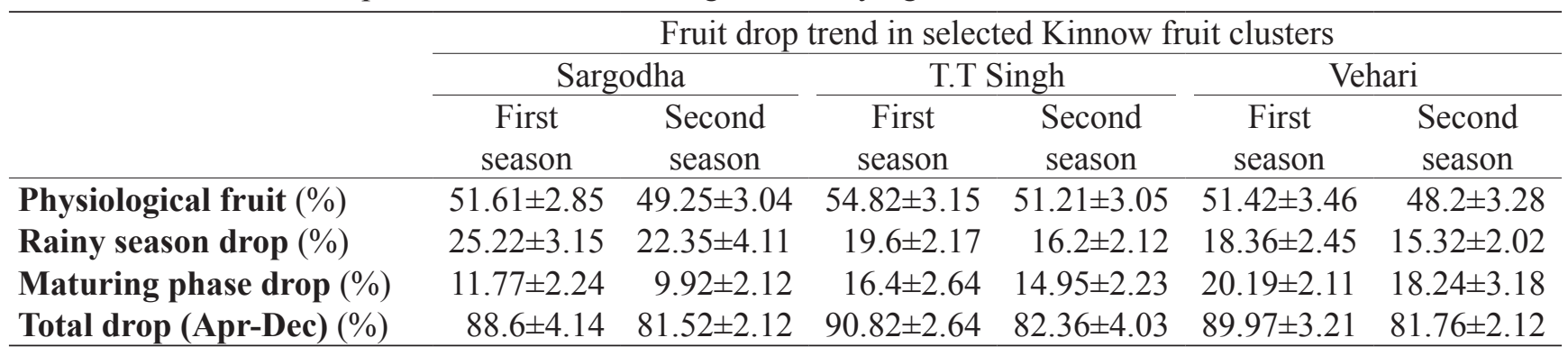

Data are shown in mean $( \pm \mathrm{SD})$. $\mathrm{SD}=$ standard deviation.

respectively. Maturing stage (October-December), fruit drop was noted at Sargodha (11.77 and 9.92\%), TTS (16.4 and 14.95\%) and Vehari (20.19 and 18.24\%) in first and second season, respectively. Total fruit drop remained non-significant among three districts but shown significant differences in both seasons.

Thind \& Kumar (2008) reported physiological drop (40-63\%) and pathological drop (5-25\%) in Kinnow mandarin. Physiological fruit drop remained dominant just after fruit-setting till cell division stage, whereas pathological fruit drop continued July till harvesting (Kumar et al., 2011). Excessive premature fruit drop was linked with environmental factors; plant nutrition and water requirement (Ibrahim et al., 2007; Ashraf et al., 2010) and pests pressure (Razi et al., 2011). In all three districts, physiological drop (April-May) was recorded as maximum when fruit cell division phase is ongoing just after fruit-setting, followed by intense heat-wave to increase plant water requirement as require to compensate carbohydrates (sink-source relation). In warm conditions of TTS and Vehari, more physiological fruit drop was observed as compared to Sargodha where rainy season resulted in more drop. Climate change has increased temperature in autumn season with increased humidity and $\mathrm{smog} /$ fog phenomenon that become more suitable for stem-end rot and fruit fly infestation, hence more drop was recorded in TTS and Vehari in autumn months when fruit maturing process occurred. Climatic variability in three locations led to more fruit drop in one or other way to influence on either physiological or pathological drops in Kinnow mandarin while inducing biennial bearing trend.

\section{CONCLUSION}

More biennial trend was seen in warm districts TTS and Vehari due to erratic behavior of weather round the year. Climatic variables influenced on fruit growth and finally on yield and quality by recording unevenness at TTS and Vehari. Harvesting time and balance in plant source-sink relation decide regular yield. Biennial bearing, an inherent phenomenon of citrus, is directly influenced by environmental factors and also induced stress by climate change. Present study has highlighted main reasons of biennial bearing will be useful in future to achieve regular bearing of fruit while doing timely harvesting and management of orchard.

\section{ACKNOWLEDGEMENTS}

HEC, Pakistan for awarding PhD Indigenous Fellowship (315-18852-2AV3-109) and Agriculture Department, Punjab Government for granting study leave. The research 
work is part of $\mathrm{PhD}$ study. Highly acknowledge Pakistan Meteorological Department, Islamabad and office of Deputy Director Agriculture (Extension) Vehari, for providing weather data of research sites.

\section{REFERENCES}

Ahmed, M. (2005). Nature and extent of fruit blemishes in Kinnow mandarin (M.Sc. research thesis). University of Agriculture Faisalabad, Pakistan.

Ashraf, M. Y., Gul, A., Ashraf, M., Hussain, F., \& Ebert, G. (2010). Improvement in yield and quality of Kinnow (Citrus deliciosa $\mathrm{x}$ Citrus nobilis) by potassium fertilization. Journal of Plant Nutrition, 33(11), 1625-1637.

Bower, J. P. (2007). The pre-and post-harvest application potential for crop- set TM and ISR2000TM on citrus. Retrieved in 2018, November 2, from http://en.engormix. com/MA agriculture/articles/th-pre

Burton, I., \& Lim, B. (2005). Achieving adequate adaptation in agriculture. Climatic Change, 70(1-2), 191-200.

Chelong, I. A., \& Sdoodee, S. (2013). Effect of climate variability and degree-day on development, yield and quality of shogun (Citrus reticulata Blanco) in Southern Thailand. Journal of Nature and Science, 47, 333-341.

Dalal, R. P. S., Beniwal, B. S., \& Sehrawat, S. K. (2013). Seasonal variation in growth, leaf physiology and fruit development in Kinnow, a mandarin hybrid. Journal of Plant Studies, 2(1), 72-77.

Davis, K., Stover, E., \& Wirth, F. (2004). Economic of fruit thinning: a review focusing on apple and citrus. HortTechnology, 14(2), 282-289.

Flore, J. A., \& Lakso, A. N. (1986). Environmental and physiological regulation of photosynthesis in fruit crops. Horticultural Reviews, 11, 111-157.

Garcia-Luis, A., Fornes, F., \& Guardiola, J. L. (1995). Leaf carbohydrates and flower formation in citrus. Journal of the American Society for Horticultural Science, 120(2), 222-227.

Ghafoor, U., Muhammad, S., \& Chaudhary, K. M. (2008). Constrains in availability of inputs and information to citrus (Kinnow) growers of tehsil Toba Tek Singh. Pakistan Journal of Agricultural Sciences, 45(4), 520-522.

Goldschmidt, E. E. (1999). Carbohydrate supply as a critical factor for citrus fruit development and productivity. HortScience, 34(6), 1020-1024.
Goldschmidt, E. E., \& Golomb, A. (1982). The carbohydrate balance of alternate-bearing citrus trees and the significance of reserves for flowering and fruiting. Journal of the American Society for Horticultural Science, 107, 206-208.

Goldschmidt, E. E., \& Koch, K. E. (1996). Citrus. In E. Zaminski, \& A. A. Schaffer (Eds.), Photoassimilate distribution in plants and crops: source-sink relations (pp. 797-823). New York: Marcel Dekker.

Hield, H. Z., \& Hilgeman, R. H. (1969). Alternate bearing and chemical fruit thinning of certain citrus varieties. Proceedings International Society of Citriculture, 3, 1145-1153.

Holland, N., Menezes, H. C., \& Lafuente, M. T. (2002). Carbohydrates as related to the heat induced chilling tolerance and respiratory rate of 'Fortune'mandarin fruit harvested at different maturity stages. Postharvest Biology and Technology, 25(2), 181-191.

Ibrahim, M., Ahmad, N., Anwar, S. A., \& Majeed, T. (2007). Effect of micronutrients on citrus fruit yield growing on calcareous soils. In F. Xu, H. E. Goldbach, P. H. Brown, R. W. Bell, \& T. Fujiwara (Eds.), Advances in plant and animal boron nutrition. Switzerland: Springer.

Iglesias, D. J., Cercós, M., Colmenero-Flores, J. M., Naranjo, M. A., Ríos, G., Carrera, E., Ruiz-Rivero, O., Lliso, I., Morillon, R., Tadeo, F. R., \& Talon, M. (2007). Physiology of citrus fruiting. Brazilian Journal of Plant Physiology, 19(4), 333-362.

Intergovernmental Panel on Climate Change - IPCC. (2007). Climate change 2007: the physical science basis. contributions of Working Group I to the fourth assessment report of the Intergovernmental Panel on Climate Change. Cambridge: Cambridge University Press.

Johnson, G. (2006). Pakistan citrus industry challenges: opportunities for Australia-Pakistan collaboration in research, development and extension. Pakistan: Citrus Industry Survey and Workshops.

Jones, G. V., White, M. A., Cooper, O. R., \& Storchmann, K. (2005). Climate change and global wine quality. Climatic Change, 73(3), 319-343.

Khan, S. R. A. (2008). Citrus quality to meet global demand. Pakissan.com. Retrieved in 2018, November 2, from http://www.pakissan.com/english/agri.overview/ citrus.quality.to.meet.global.demand

Kumar, A., Avasthe, R. K., Pandey, B., Lepcha, B., \& Rahman, H. (2011). Effect of fruit size and orchard 
location on fruit quality and seed traits of mandarin (Citrus reticulata) in Sikkim Himalayas. Indian Journal of Agricultural Sciences, 81(9), 821.

Ladaniya, M. S. (2011). Physico-chemical, respiratory and fungicide residue changes in wax coated mandarin fruit stored at chilling temperature with intermittent warming. Journal of Food Science and Technology, 48(2), 150-158.

Mahmood, M. A., \& Sheikh, A. D. (2006). Citrus export system in Pakistan. Journal of Agricultural Research, 44, 229-237.

Monselise, S. P., \& Goldschmidt, E. E. (1982). Alternate bearing in fruit trees. Horticultural Reviews, 4, 128-173.

Moss, G. I., Bellamy, J., \& Bevington, K. B. (1974). Controlling biennial bearing. Australian Citrus News, 50, 6-7.

Nawaz, R., Abbasi, N. A., Ahmad Hafiz, I., Khalid, A., Ahmad, T., \& Aftab, M. (2019a). Impact of climate change on Kinnow fruit industry of Pakistan. Agrotechnology, 8(186), 2.

Nawaz, R., Akhtar Abbasi, N., Ahmad Hafiz, I., \& Khalid, A. (2019b). Color-break effect on Kinnow (Citrus nobilis Lour x Citrus deliciosa Tenora) fruit's internal quality at early ripening stages under varying environmental conditions. Scientia Horticulturae, 256, 108514.

Nawaz, R., Abbasi, N. A., Hafiz, I. A., Khan, Z., Khan, M. R., \& Khalid, A. (2019c). Impact of peel coloration on internal quality of Kinnow mandarin (Citrus nobilis Lour x Citrus deliciosa Tenora) at early ripening stage. World Journal of Biology and Biotechnology, 4(1), 7-17.

Nawaz, R., Abbasi, N. A., Hafiz, I. A., \& Khalid, A. (2020a). Impact of climate variables on growth and development of Kinnow fruit (Citrus nobilis Lour x Citrus deliciosa Tenora) grown at different ecological zones under climate change scenario. Scientia Horticulturae, 260, 108868.

Nawaz, R., Abbasi, N. A., Hafiz, I. A., \& Khalid, A. (2020b). Increasing level of abiotic and biotic stress on Kinnow fruit quality at different ecological zones in climate change scenario. Environmental and Experimental Botany, 171, 103936.

Nishikawa, F., Iwasaki, M., Fukamachi, H., \& Matsumoto, H. (2016). The effect of fruit bearing on low-molecularweight metabolites in stems of Satsuma Mandarin (Citrus unshiu Marc.). The Horticulture Journal, 85(1), 23-29.

Pakistan. (2017). Statistical Bureau of Pakistan. Islamabad: Provincial Crops Reporting Service.
Parry, M. L., Rosenzweig, C., Iglesias, A., Livermore, M., \& Fischer, G. (2004). Effects of climate change on global food production under SRES emissions and socio-economic scenarios. Global Environmental Change, 14(1), 53-67.

Pakistan Horticulture Development \& Export Company - PHDEC. (2017). Islamabad..

Pakistan Horticulture Development \& Export Company - PHDEC. (2018). Islamabad.

Razi, M. F. D., Khan, I. A., \& Jaskani, M. J. (2011). Citrus plant nutritional profile in relation to Huanglongbing prevalence in Pakistan. Pakistan Journal of Agricultural Sciences, 48, 299-304.

Sharma, N., Sharma, S., \& Niwas, R. (2017). Thermal time and phenology of citrus in semi-arid conditions. Journal of Pharmacognosy and Phytochemistry, 6(5), 27-30.

Trade Development Authority of Pakistan - TDAP. (2010). Annual report. Islamabad.

Trade Development Authority of Pakistan - TDAP. (2017). Annual report. Islamabad.

Trade Development Authority of Pakistan - TDAP. (2018). Annual report. Islamabad.

Thind, S. K., \& Kumar, K. (2008). Integrated management of fruit drop in Kinnow mandarin. Indian Journal of Horticulture, 65(4), 497-499.

Tubiello, F. N., Rosenzweig, C., Goldberg, R. A., Jagtap, S., \& Jones, J. W. (2002). Effects of climate change on US crop production: simulation results using two different GCM scenarios. Part I: wheat, potato, maize, and citrus. Climate Research, 20, 259-270.

Ullah, R., Shivakoti, G. P., \& Ali, G. (2015). Factors effecting farmers' risk attitude and risk perceptions: the case of Khyber Pakhtunkhwa, Pakistan. International Journal of Disaster Risk Reduction, 13, 151-157.

Usman, M., Ashraf, I., Chaudhary, K. M., \& Talib, U. (2018). Factors impeding citrus supply chain in central Punjab, Pakistan. International Journal of Agricultural Extension, 6, 1-5.

Wheaton, T. A. (1992). Alternate bearing of citrus. Proc. Intl. Seminar Citriculture, 1, 224-228.

Whiley, A. W., Rasmussen, T. S., Saranah, J. B., \& Wolstenholme, B. N. (1996). Delayed harvest effects on yield, fruit size and starch cycling in avocado (Persea americana Mill.) in subtropical environments. I. the earlymaturing cv. Fuerte. Scientia Horticulturae, 66(1-2), 23-34. 
Yakushiji, H., Nonami, H., Fukuyama, T., Ono, S., Takagi, N., \& Hashimoto, Y. (1996). Sugar accumulation enhanced by osmoregulation in satsuma mandarin fruit. Journal of the American Society for Horticultural Science, 121(3), 466-472.

Zekri, M. (2011). Factors affecting citrus production and quality. Citrus Industry. Retrieved in 2018, November 2, from crec.ifas.ufl.edu

Zekri, M., \& Rouse, R. E. (2002). Citrus problems in the home landscape. Gainesville: University of Florida.
Received: November 02, 2018

Accepted: December 03, 2019

How to cite: Nawaz, R., Abbasi, N. A., Hafiz, I. A., \& Khalid, A. (2019).

Influence of varying environmental conditions on biennial bearing habit of Kinnow fruit (Citrus nobilis Lour x C. deliciosa Tenora) grown at different clusters in the Punjab province, Pakistan. Citrus Research \& Technology, 40, e1053. https://doi.org/10.4322/crt.17019. 